\title{
PHYSIOLOGICAL EFFECTS OF CRUDE CHITINASE FROM AEROMONAS HYDROPHILA ON THE GREATER WAX MOTH; GALLERIA MELLONELLA L. (LEPIDOPTERA: PYRALIDAE)
}

\author{
Aly, Hamdy H. ${ }^{1}$, Abdel Naser A. Kobisi ${ }^{*}$, Shereen M. Korany ${ }^{2}$, \\ Hoda H. El-Hendawy ${ }^{2}$ and Amany N. Mansour ${ }^{1}$ \\ ${ }^{1}$ Department of Plant Protection, Desert Research Center, Cairo, Egypt \\ ${ }^{2}$ Department of Botany and Microbiology, Faculty of Science, Helwan \\ University, Cairo, Egypt \\ *E-mail: nkobisi@yahoo.com
}

\begin{abstract}
T $\mathrm{n}$ a laboratory study, the impact of crude chitinase from Aeromonas hydrophila on the nutrient indices and on the major biochemical components of Galleria mellonella was studied. Fourth larval instar of Galleria mellonella was treated with 135.0 U/mg protein $\left(\mathrm{LC}_{50}\right)$. Treatment with crude chitinase reduced the larval feeding efficiency, retarded larval growth and reduced larval weight, whereas approximate digestibility was increased. The total protein contents in the supernatant of the homogenate larvae post-treatment was decreased, as affected by crude chitinase $\left(\mathrm{LC}_{50}\right)$ comparing with the check treatment. A significant reduction in the total lipid content was observed and it may due to its conversion to proteins in order to compensate the reduction in protein content or to produce supplementary energy. The total carbohydrate contents were significantly reduced to be $\sim 111.17 \pm 4.24 \mu \mathrm{g} /$ larva with respect to the control (147.21 $\pm 1.77 \mu \mathrm{g} / \mathrm{larva})$. Crude chitinase from Aeromonas hydrophila may serve as a powerful biocontrol tool against insects and provide a suitable substitute for synthetic pesticides.
\end{abstract}

Keywords: Chitinolytic bacteria, nutrient indices, feeding efficiency, larval biochemical components

Pesticides have been frequently used to control insect pests through the second half of the $20^{\text {th }}$ century. However, the limitation in chemical control application is increasing due to the rapid development of insecticide resistance (Rausell et al., 2004) and also the accumulation of their chemical residues,

The $1^{\text {st }}$ Conference of Plant Protection Science Applications for Sustainable Development of Desert Areas "Effect of Climate Change on Plant Pests and Biodiversity in Desert Environment" 19-20 October, 2019, Cairo-Egypt. 
which are difficult to degrade (Ye et al., 2018). Therefore, biological control has been chosen as an alternative to reduce chemical pesticide usage (Nurdebyandaru et al., 2010). Biopesticides are generally less toxic than synthetic pesticides, often target specific pests and have little or no residual effects. Hence, they pose less risks to human health, environment and can be used in the organic farming (Kumar, 2012).

In insects, chitin is present in the body wall or cuticle, gut lining, salivary glands, tracheal tubes, eggshells and muscles in assorted combinations with protein and other components depending on the species and the desired physical properties (Kramer and Koga, 1986). Therefore, it is a great target for controlling insect pests.

Chitinases (E.C. 3.2.1.14) are a group of enzymes that play a pivotal role in recycling chitin in nature. They are produced by organisms such as bacteria, fungi, actinomycetes, insects and high plants. Additionally, they are known to perform many biological functions (Jabeen et al., 2018). This enzyme may damage the peritrophic membrane that lines the midgut and protects the epithelial cells, which play an essential role in insect feeding (Bonnay et al., 2013). Once peritrophic membrane degraded by chitinase, insect feeding may stop and consequently the insect undergoes a lot of suffering or death (Bahar et al., 2012). Moreover, epithelium becomes indefensible and therefore, microbial pathogens may invade the insect hemocoel where it multiplies and lead to death due to septicemia (Aggarwal et al., 2017).

This investigation was carried out to determine the effect of crude chitinase enzyme $\left(\mathrm{LC}_{50}\right)$ produced by Aeromonas hydrophila on feeding behavior, development and biochemical parameters of Galleria mellonella.

\section{MATERIALS AND METHODS}

\section{Insect Rearing}

The greater wax moth; Galleria mellonella was obtained from a colony maintained at insectaries of Plant Protection Department, Desert Research Center, Cairo, Egypt. Larvae were reared on artificial diet described by Metwally et al. (2012). All rearing steps of the colony and experiments were kept under laboratory conditions of $30 \pm 2^{\circ} \mathrm{C}$ and R.H. $70 \pm 5 \%$.

\section{Source of Crude Chitinase Enzyme}

Aeromonas hydrophila was isolated from brackish water sample collected from Siwa Oasis, Egypt. The pathogenic activity of this bacterial species against Galleria mellonella, its potentiality for chitinase production and the $\mathrm{LC}_{50}$ value of the crude chitinase were determined (Korany et al., 2019). According to the later authors, the $\mathrm{LC}_{50}$ of crude chitinase was found to be $135.0 \mathrm{U} / \mathrm{mg}$ protein and had been used through this study. 


\section{Antifeedant Activity}

The experiment was performed with the fourth larval instar of Galleria mellonella. One gram of artificial diet was mixed with $0.1 \mathrm{ml}$ of $\mathrm{LC}_{50}$ of crude chitinase. The larvae were starved for $24 \mathrm{~h}$ prior to the treatment. Five larvae were weighed and transferred to petri dishes containing the artificial diet mixed with crude chitinase and left for three days. Ten replicates were used during the experiments. Fifty control larvae were fed on untreated artificial diet and followed the same regime. The weights of live larvae, feces, the remaining artificial diet and the dead larvae, if occurred, were recorded at the end of the experiment. The following calculation aspects were done according to Waldbauer (1968). All calculations were based on larval fresh weight in $\mathrm{mg}$.

\subsection{Relative consumption rate $(\mathrm{RCR})=\frac{\mathrm{F}}{\mathrm{TA}}$}

$\mathrm{F}=$ consumed food $(\mathrm{mg}), \mathrm{T}=$ duration of feeding period ( 3 days) and $\mathrm{A}=$ Mean fresh weight of larvae during feeding period (mg).

\subsection{Relative growth rate $(\mathrm{RGR})=\frac{\mathrm{G}}{\mathrm{TA}}$}

$\mathrm{G}=$ fresh gain of larval weight during feeding period, $\mathrm{T}=$ duration of feeding period ( 3 days) and $\mathrm{A}=$ Mean fresh weight of larvae during feeding period (mg).

3.3. Efficiency of conversion of ingested food to body substance (ECI \%) $=\frac{\text { RGR }}{\text { RCR }} \times 100$

\subsection{Approximate digestibility (A.D.) $=$ wt of food ingested-wt of feces}

\subsection{Growth inhabitation $=\frac{\text { GL }- \text { TL }}{\text { GL }} \times 100$}

wt of food ingested treatment.

$\mathrm{GL}=$ Larval weight gain in control and $\mathrm{TL}=$ Larval weight gain in

\subsection{Feeding deterrence index $\left(\right.$ FDI \%) $=(C-T) \times \frac{100}{C}$}

$\mathrm{C}=$ the larval consumption of the control artificial diet and $\mathrm{T}=$ the larval consumption of the treated artificial diet (Khani et al., 2012).

\section{Biochemical Studies}

The experiment was performed with ten replicates of Galleria mellonella fourth larval instar using 1 gram of artificial diet mixed with 0.1 $\mathrm{ml}$ of $\mathrm{LC}_{50}$ of crude chitinase.

\subsection{Estimation of total protein}

Each larva was homogenized in $100 \mu \mathrm{l}$ of phosphate buffer $(\mathrm{pH} 7.0$, $20 \mathrm{mM}$ ), then the homogenate was centrifuged at $12,000 \mathrm{rpm}$ for 12 minutes at $10^{\circ} \mathrm{C}, 10 \mu \mathrm{l}$ of supernatant was mixed with $500 \mu \mathrm{l}$ Bradford reagent $(10 \mathrm{mg}$ Coomassie blue G250, $5 \mathrm{ml}$ ethanol and $10 \mathrm{ml}$ phosphoric acid) (Bradford, 1976). After 30 minutes, the absorbance at $630 \mathrm{~nm}$ was recorded and protein 
content was determined using bovine serum albumin (BSA) as standard (Piri et al., 2014).

\subsection{Carbohydrate determination}

Carbohydrate was extracted according to Van Handel (1965) method. One larva was homogenized in $62.5 \mu 1$ of sodium sulphate solution $(2 \%$ $\left.\mathrm{Na}_{2} \mathrm{SO}_{4}\right)$ and mixed with $468.75 \mu \mathrm{l}$ of chloroform/methanol $(1: 2 \mathrm{v} / \mathrm{v})$. The homogenate was centrifuged at $8,000 \mathrm{rpm}$ for 10 minutes at $10^{\circ} \mathrm{C}$. Then 150 $\mu 1$ of the supernatant was transferred into a micro tube and $100 \mu 1$ of distilled water and $500 \mu$ of anthrone reagent $(0.05 \%$ in sulphuric acid) were added to each tube and heated in a $90^{\circ} \mathrm{C}$ water bath for 10 minutes. The blank consisted of $100 \mu \mathrm{l}$ distilled water, $500 \mu \mathrm{l}$ anthrone reagent, and $150 \mu 1 \mathrm{Na}_{2} \mathrm{SO}_{4}(2 \%)$ and chloroform/methanol. The absorbance at $630 \mathrm{~nm}$ was recorded. Carbohydrate content was measured with maltose as standard.

\subsection{Estimation of total lipid}

Lipid content was determined according to the method of Van Handel (1965). Two larvae were homogenized in $100 \mu \mathrm{l}$ of $\mathrm{Na}_{2} \mathrm{SO}_{4}(2 \%)$ and then were mixed with $750 \mu 1$ of chloroform/methanol (1: $2 \mathrm{v} / \mathrm{v})$. The homogenate was centrifuged at $8000 \mathrm{rpm}$ for 10 minutes at $10^{\circ} \mathrm{C}$. Then, $125 \mu \mathrm{l}$ of the supernatant was transferred into Eppendrof tubes and heated in an oven at $40^{\circ} \mathrm{C}$ until complete evaporation of the solvent. Then, $125 \mu \mathrm{l}$ of sulphuric acid (98\%) was added to each tube and heated at a $90^{\circ} \mathrm{C}$ water bath for 10 minutes. After that, $30 \mu \mathrm{l}$ of the sample was transferred to a microplate and incubated with $270 \mu \mathrm{l}$ vanillin reagent ( $0.006 \mathrm{~g}$ vanillin, $4 \mathrm{ml}$ phosphoric acid, and $1 \mathrm{ml}$ distilled water). After 30 minutes incubation with the reagent, the reddish color was developed. The absorbance of the sample (A sample) and standard (A standard) against reagent blank at $545 \mathrm{~nm}$ was recorded. The absorbance of the sample (A sample) and standard (A standard) against reagent blank at $545 \mathrm{~nm}$ was recorded.

\section{Statistical Analysis}

Data were analyzed with independent t-test using SPSS statistical program. All data were graphically presented as the mean \pm SE using Microsoft Excel 2010.

\section{RESULTS}

\section{Antifeedant Activity of Crude Chitinase Against Galleria mellonella $4^{\text {th }}$ Instar Larvae}

Feeding deterrence indices (FDI) demonstrated that crude chitinase (135.0 U/mg protein) has an effective feeding deterrence on Galleria mellonella larvae as shown in table (1). Chitinase has clearly reduced both relative growth rate (RGR) and relative food consumption rate (RCR) of Galleria mellonella. Approximate digestibility (AD) of treated larvae was increased $(75.67 \%)$ as compared to control $(73.00 \%)$. On the other hand,

Egyptian J. Desert Res., 69, Special Issue, 101-111 (2019) 
efficiency of conversion of ingested food (ECI) was decreased $(24.51 \%)$ as compared to control $(26.73 \%)$. Disturbance in the relation between consumed food and the amount of feces hampered and suppressed the larval growth. This was revealed by the value of growth inhibition (GRI) that represented by $75.67 \%$.

Table (1). Effect of crude chitinase $\left(\mathrm{LC}_{50}\right)$ on nutritional and feeding deterrence indices of Galleria mellonella fourth larval instar.

\begin{tabular}{ccccccc}
\hline $\begin{array}{c}\text { Conc. (U/mg } \\
\text { protein) }\end{array}$ & $\begin{array}{c}\mathbf{R C R} * * \\
\mathbf{m g} / \mathbf{m g} / \mathbf{d a y} \\
\pm \mathbf{S E}\end{array}$ & $\begin{array}{c}\mathbf{R G R} \\
\mathbf{m g} / \mathbf{m g} / \mathbf{d a y} \\
\pm \text { SE }\end{array}$ & $\begin{array}{c}\text { ECI } \\
\mathbf{( \% )}\end{array}$ & $\begin{array}{c}\text { FDI } \\
\mathbf{( \% )}\end{array}$ & $\begin{array}{c}\text { AD } \\
\mathbf{( \% )}\end{array}$ & $\begin{array}{c}\text { GRI } \\
\mathbf{( \% )}\end{array}$ \\
\hline 0 & $12.43 \pm 0.04^{\mathrm{a}^{*}}$ & $3.26 \pm 0.01^{\mathrm{a}}$ & 26.73 & - & 73.00 & - \\
135 & $7.00 \pm 0.06^{\mathrm{b}}$ & $1.77 \pm 0.01^{\mathrm{b}}$ & 24.51 & 72.73 & 75.67 & 75.67 \\
t-statistic (df) & $3.45(15.24)$ & $4.76(17.22)$ & - & - & - & \\
P-value & 0.003 & 0.000 & - & - & - & - \\
\hline
\end{tabular}

*Each data represents the mean of 10 replicates.

${ }^{* *}$ RCR-Relative consumption rate; RGR-Relative growth rate; ECI-efficiency of conversion of ingested food; FDI-feeding deterrence index; GRI-growth inhibition and $\mathrm{AD}$-approximate digestibility.

\subsection{Biochemical studies}

4.2.1. Effect of crude chitinase $\left(L^{2} C_{50}\right)$ on total protein, lipids and carbohydrates of Galleria mellonella

Total proteins, lipids and carbohydrates in both crude chitinase (135.0 $\mathrm{U} / \mathrm{mg}$ protein) treated and untreated Galleria mellonella fourth larval instar was shown in table (2). The crude chitinase has clearly induced alteration of biochemical parameters in treated larvae. Protein in treated larvae recorded $18.94 \pm 0.38 \mu \mathrm{g} /$ larva comparing with the control $(19.52 \pm 0.17 \mu \mathrm{g} / \mathrm{larva})$. In the same way, the level of total carbohydrates in treated larvae was also reduced $(111.17 \pm 4.24 \mu \mathrm{g} / \mathrm{larva})$ compared to the control $(147.21 \pm 1.77 \mu \mathrm{g} /$ larva $)$. Similarly, the lipid level showed a prominent turn down $(223.77 \pm 2.00$ $\mathrm{mg} / \mathrm{dl} / \mathrm{larva}$ ) with the treatment of crude chitinase in contrast with that of the control larvae $(519.91 \pm 2.17 \mathrm{mg} / \mathrm{dl} / \mathrm{larva})$.

Table (2). Effect of crude chitinase $\left(\mathrm{LC}_{50}\right)$ on biochemical parameters of Galleria mellonella fourth larval instar homogenate (after $72 \mathrm{~h}$ ).

\begin{tabular}{cccc}
\hline $\begin{array}{c}\text { Conc. } \\
(\mathbf{U} / \mathbf{m g} \text { protein) }\end{array}$ & $\begin{array}{c}\text { Total protein } \\
(\boldsymbol{\mu g} / \mathbf{l a r v a} \pm \mathbf{S E})\end{array}$ & $\begin{array}{c}\text { Total lipids } \\
(\mathbf{m g} / \mathbf{d l} / \mathbf{l a r v a} \pm \mathbf{S E})\end{array}$ & $\begin{array}{c}\text { Total carbohydrates } \\
(\boldsymbol{\mu g} / \mathbf{l a r v a} \pm \mathbf{S E})\end{array}$ \\
\hline 0 & $19.52 \pm 0.17^{\mathrm{a}^{*}}$ & $519.91 \pm 2.17^{\mathrm{a}}$ & $147.21 \pm 1.77^{\mathrm{a}}$ \\
135 & $18.94 \pm 0.38^{\mathrm{b}}$ & $223.77 \pm 2.00^{\mathrm{b}}$ & $111.17 \pm 4.24^{\mathrm{b}}$ \\
t-statistic (df) & $1.38(28.00)$ & $98.41(27.94)$ & $7.837(28.00)$ \\
P-value & 0.177 & 0.000 & 0.000 \\
\hline
\end{tabular}

${ }^{*}$ Each data represents the mean of 10 replicates. 


\section{DISCUSSION}

Chitinase has been used previously as an insecticide and a fungicide (Senthil-Nathan et al., 2009). Mortality of Aphis gossypii G. (Hemiptera: Aphididae) was exceeded when chitinase was integrated with Bacillus subtilis compared to treatment with the bacteria alone, and this result was interrelated with enzyme levels (Abdullah et al., 2014).

The potentiality of chitinase in the present study was similar to that reported by Thamthiankul et al. (2004) and Chandrasekaran et al. (2012). Microbial chitinases may partially digest the peritrophic membrane and may assists the microbes and their toxins to penetrate the peritrophic membrane (Thamthiankul et al., 2004).

The inhibitory effects of crude chitinase $\left(\mathrm{LC}_{50}\right)$ of Aeromonas hydrophila on nutritional physiology of Galleria mellonella were studied. Where, the decrease in relative consumption and growth rate of larvae feeding on diet supplemented with crude chitinase indicate the antifeedant effect. The present outcomes agreed with the results obtained by Senthil-Nathan et al. (2007), who reported that the relative growth rate and the relative consumption rate (RGR and RCR) of Spodoptera strains were decreased significantly when treated with toxins and secondary metabolites of Bacillus spp.

Efficiency of conversion of ingested food to body substance (ECI) is an overall measure of an insect's ability to utilize the food that it ingests for growth. In which, decreasing of ECI values indicate that ingested crude chitinase exhibit some chronic toxicity on Galleria mellonella. The reduction in ECI percentage may results from a food conversion deficiency that reduces growth. This may perhaps occur through a diversion of energy from biomass production to detoxification (Wheeler et al., 2001).

In physiological studies, proteins are fundamental components of all living cells in terms of their vital effects on the important fitness-associated traits of the individual-level such as body size, growth rate and fecundity. In addition, their high levels are linked to population dynamics, life histories and even biological diversification. Therefore, proteins are necessary for the proper functioning of any organism (Kamel et al., 2010). The obtained results showed a significant reduction of protein content or titer after $72 \mathrm{~h}$ of treatment exposure. Nath et al. (1997) suggested that this could be due to the breakdown of protein into amino acids, so with the entrance of these amino acids to TCA cycle as a keto acid, they will help to supply energy for the insect. So, protein depletion in tissues may constitute a physiological mechanism and might play a role in compensatory mechanisms under insecticidal stress to provide intermediates to the Krebs cycle by retaining free amino acid content in hemolymph. This observation agreed with Vijayakumar et al. (2016), who found that chitinase from Trichoderma viride suppressed

Egyptian J. Desert Res., 69, Special Issue, 101-111 (2019) 
protein synthesis of Corcyra cephalonica Ragonot (Lepidoptera: Pyralidae) larvae, $72 \mathrm{~h}$ post treatment.

Carbohydrates contribute to the structure and functions of all insect tissues and can be found in the nuclei, cytoplasm, and membranes of cells, as well as in the extracellular hemolymph and supporting tissues (Chippendale, 1978). Also, many carbohydrates such as sugars are powerful feeding stimulants (Nation, 2001). The obtained data showed that when Galleria mellonella larvae were treated at $\mathrm{LC}_{50}$ of crude chitinase, their carbohydrate content got decreased. The reduction of carbohydrates may be due to the effect of anti-feeding and increased metabolism under toxicant stress. Remia et al. (2008) suggested that the reduction in carbohydrates is due to the possibility of active glycogenolysis and glycolytic pathway to provide excess energy under the stress conditions. The present results of carbohydrate decrease after treatment also agree with those obtained by many investigators such as Abuldahab et al. (2011), Rashwan (2013) and Piri et al. (2014).

Lipids are the most suitable materials for energy storage (Beenakkers et al., 1985). Relative to carbohydrates, lipids can supply as much as eight times more energy per unit weight. The reduction of lipids during the context of the current study after $72 \mathrm{~h}$ of exposure could be attributed to the their conversion into proteins in order to substitute the reduction in the protein content or to produce supplementary energy (Abuldahab et al., 2011).

\section{CONCLUSION}

The present study indicated that chitinase enzyme produced by Aeromonas hydrophila greatly influenced some metabolic processes of Galleria mellonella. This was evidenced by the marked differences in the feeding, growth rate, and biochemical parameters such as total protein, lipid and carbohydrates. Hence, the entomopathogenic chitinolytic bacteria can serve as a cost competitive alternative of the synthetic pesticides.

\section{REFERENCES}

Abdullah, R.R., N.A. Sukar and N.M. Ghanim (2014). Improving efficacy of Bacillus thuringiensis against Insects of different feeding habits by plasmid transfer technique of chitinase. Egyptian Journal of Biological Pest Control, 24: 37.

Abuldahab, F., Y. Abozinadah and S. Al-Haiqi (2011). Impact of Bacillus thuringiensis exotoxin to some biochemical aspects of Musca domestica (Diptera: Muscidae). African Journal of Bacteriology Research, 3: 92-100.

Aggarwal, C., S. Paul, V. Tripathi, B. Paul and M.A. Khan (2017). Characterization of putative virulence factors of Serratia marcescens 
strain SEN for pathogenesis in Spodoptera litura. Journal of Invertebrate Pathology, 143: 115-123.

Bahar, A.A., K. Sezen, Z. Demirbağ and R. Nalçacioğlu (2012). The relationship between insecticidal effects and chitinase activities of Coleopteran-originated entomopathogens and their chitinolytic profile. Annals of Microbiology, 62: 647-653.

Beenakkers, A.M.T., D.J. Van Der Horst and W.J.A. Van Marrewijk (1985). 13 - Biochemical Processes Directed to Flight Muscle Metabolism A2 - KERKUT, G.A. In: "Biochemistry", Gilbert, L.I. (Ed.). Amsterdam: Pergamon, pp. 451-486,

Bonnay, F., E. Cohen-Berros, M. Hoffmann, S.Y. Kim, G.L. Boulianne, J.A. Hoffmann, N. Matt and J.M. Reichhart (2013). Big bang gene modulates gut immune tolerance in Drosophila. Proceedings of the National Academy of Sciences, 110: 2957-2962.

Bradford, M.M. (1976). A rapid and sensitive method for the quantitation of microgram quantities of protein utilizing the principle of protein-dye binding. Analytical Biochemistry, 72: 248-254.

Chandrasekaran, R., K. Revathi, S. Nisha, S.A. Kirubakaran, S. SathishNarayanan and S. Senthil-Nathan (2012). Physiological effect of chitinase purified from Bacillus subtilis against the tobacco cutworm Spodoptera litura Fab. Pesticide Biochemistry and Physiology, 104: 65-71.

Chippendale, G.M. (1978). The Functions of Carbohydrates in Insect Life Processes. In: Rockstein, M. (ed.) Biochemistry of Insects. Academic Press, New York, pp. 2-55.

Jabeen, F., A. Hussain, M. Manzoor, T. Younis, A. Rasul and J.I. Qazi (2018). Potential of bacterial chitinolytic, Stenotrophomonas maltophilia, in biological control of termites. Egyptian Journal of Biological Pest Control, 28: 86.

Kamel, A.S., M. Aziz and N.M. El-Barky (2010). Biochemical effects of three commercial formulations of Bacillus thuringiensis (Agerin, Dipel 2X and Dipel DF) on Spodoptera littoralis larvae. Egypt. Acad. J. Biolog. Sci., 3: 21-29.

Khani, M., R.M. Awang, D. Omarand and M. Rahmani (2012). Bioactivity effect of Piper nigrum L. and Jatropha curcas L. extracts against Corcyra cephalonica. Agrotechnology, 2 (1): 1-6.

Korany, S.M., A.N. Mansour, H.H. El-Hendawy, A.A. Kobisi and H.H. Aly (2019). Entomopathogenic efficacy of the chitinolytic bacteria: Aeromonas hydrophila isolated from Siwa Oasis, Egypt. Egyptian Journal of Biological Pest Control, 29 (16): 1-10.

Kramer, K.J. and D. Koga (1986). Insect chitin. Insect Biochemistry, 16: 851-877.

Kumar, S. (2012). Biopesticides: a need for food and environmental safety. J. Biofertil. Biopestic., 3: 1-3.

Egyptian J. Desert Res., 69, Special Issue, 101-111 (2019) 
Metwally, H.M., G.A. Hafez, M.A. Hussein, M. Hussein, H. Salem and M. Saleh (2012). Low cost artificial diet for rearing the greater wax moth, Galleria mellonella L. (Lepidoptera: Pyralidae) as a host for entomopathogenic nematodes. Egyptian Journal of Biological Pest Control, 22: 15-17.

Nath, B.S., A. Suresh, B.M. Varma and R.S. Kumar (1997). Changes in protein metabolism in hemolymph and fat body of the silkworm, Bombyx mori (Lepidoptera: Bombycidae) in response to organophosphorus insecticides toxicity. Ecotoxicology and Environmental Safety, 36: 169-173.

Nation, J.L. (2001). IN: 'Insect Physiology and Biochemistry". CRC press,Boca Raton.

Nurdebyandaru, N., N.R. Mubarik and T.S. Prawasti (2010). Chitinolytic bacteria isolated from Chili rhizosphere: Chitinase characterization and application as biocontrol for Aphis gossypii. Microbiology Indonesia, 4: 103-107.

Piri, F., A. Sahragard and M. Ghadamyari (2014). Sublethal effects of spinosad on some biochemical and biologicalparameters of Glyphodes pyloalis Walker. Plant Protection Science, 50: 135-144.

Rashwan, M.H. (2013). Biochemical impacts of rynaxypyr (Coragen) and spinetoram (Radiant) on Spodoptera littoralis (Boisd.). Nature and Science, 11: 40-47.

Rausell, C., I. Garcia-Robles, J. Sánchez, C. Munoz-Garay, A. MartınezRamirez, M. Real and A. Bravo (2004). Role of toxin activation on binding and pore formation activity of the Bacillus thuringiensis Cry3 toxins in membranes of Leptinotarsa decemlineata (Say). Biochimica et Biophysica Acta (BBA)-Biomembranes, 1660: 99-105.

Remia, K., S. Logaswamy, K. Logankumar and D. Rajmohan (2008). Effect of an insecticide (Monocrotophos) on some biochemical constituents of the fish Tilapia mossambica. Poll. Res., 27: 523-526.

Senthil-Nathan, S., M.Y. Choi, C.H. Paik and H.Y. Seo (2007). Food consumption, utilization, and detoxification enzyme activity of the rice leaffolder larvae after treatment with Dysoxylum triterpenes. Pesticide Biochemistry and Physiology, 88: 260-267.

Senthil-Nathan, S., K. Kalaivani, M.Y. Choi and C.H. Paik (2009). Effects of jasmonic acid-induced resistance in rice on the plant brownhopper, Nilaparvata lugens Stål (Homoptera: Delphacidae). Pesticide Biochemistry and Physiology, 95: 77-84.

Thamthiankul, S., W.J. Moar, M.E. Miller and W. Panbangred (2004). Improving the insecticidal activity of Bacillus thuringiensis subsp. aizawai against Spodoptera exigua by chromosomal expression of a chitinase gene. Appl. Microbiol. Biotechnol., 65: 183-192.

Van Handel, E. (1965). Microseparation of glycogen, sugars, and lipids. Analytical Biochemistry, 11: 266-271. 
Vijayakumar, N., S. Alagar and N. Madanagopal (2016). Effects of chitinase from Trichoderma viride on feeding, growth and biochemical parameters of the rice moth, Corcyra cephalonica Stainton. Journal of Entomology and Zoology Studies, 4: 520-523.

Waldbauer, G. (1968). The consumption and utilization of food by insects. Advances in Insect Physiology, 5: 229-288.

Wheeler, G., F. Slansky and S. Yu (2001). Food consumption, utilization and detoxification enzyme activity of larvae of three polyphagous noctuid moth species when fed the botanical insecticide rotenone. Entomologia Experimentalis et Applicata, 98: 225-239.

Ye, X., F. Dong and X. Lei (2018). Microbial resources and ecology-microbial degradation of pesticides. Natural Resources Conservation and Research, 1 (1): 22-28.

Egyptian J. Desert Res., 69, Special Issue, 101-111 (2019) 


\section{التأثير ات القسيولوجية لمستخلص الكيتينيز من Aeromonas

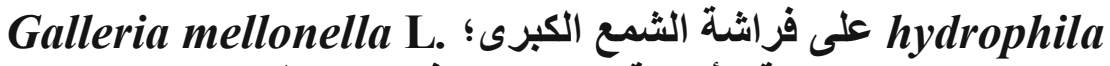 (حرشفية الأجنحة: الفراشات ذات الخرى الخرط)}

حمدى حسين علي'، عبد الناصر أحمد قبيصي'، شيرين مجدي قرني '، هدى حامد هنداوي

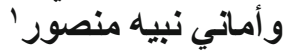

'قسم وقاية النبات، مركز بحوث ملهوث الصحر اءه، المطرية، القاهرة، مصر

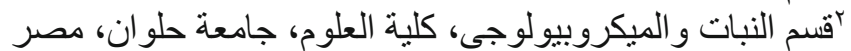

تمت دراسة تأثثر مستخلص الكيتينيز من بكتيريا Aeromonas hydrophila المعزولة

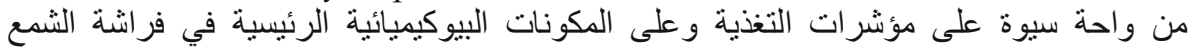

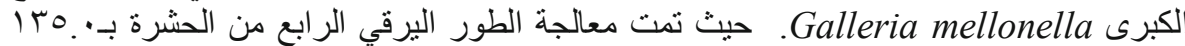

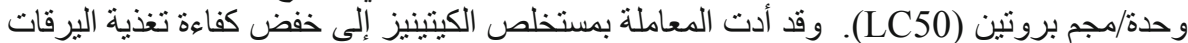

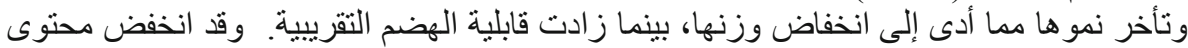

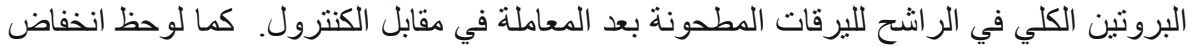

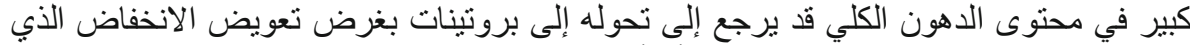

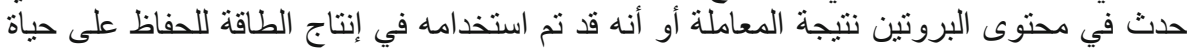



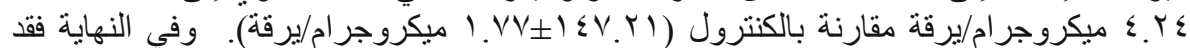

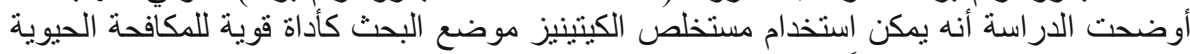

ضد الحشر ات مما يوفر بديلاً مناسبًا لمبيدات الآفات الهنات الكيميائية. 